\title{
Optimizing Online Learning during Covid 19 Pandemic in Junior High School
}

\author{
Rojif Mualim $^{1 凶}$, M Fachdir Saputra $^{2}$ \\ Magister Pendidikan Agama Islam, Universitas Muhammadiyah Surakarta, Indonesia ${ }^{1}$ \\ Program Doktoral Pascasarjana UIN Sunan Kalijaga Yogyakarta, Indonesia ${ }^{2}$ \\ email: rojifmualim@gmail.com ${ }^{1}$, fachdir.saputra15@gmail.com
}

\begin{tabular}{|c|c|}
\hline Article info & Abstract \\
\hline $\begin{array}{l}\text { Article History } \\
\text { Recieved: } \\
\text { 31/03/2021 } \\
\text { Accepted: } \\
\text { 27/04/2021 } \\
\text { Published: } \\
\text { 10/05/2021 } \\
\square \\
\text { Corresponding Author }\end{array}$ & $\begin{array}{l}\text { Covid } 19 \text { pandemic has changed people life, including education, in Indonesia. } \\
\text { This research aims to describe Islamic education (PAI) teachers' efforts to } \\
\text { optimize the online learning during pandemic. Descriptive qualitative was chosen } \\
\text { as the method of this research. The research subjects were Islamic education } \\
\text { teachers at SMPN } 7 \text { Sukoharjo, and the informants were teachers, principal, and } \\
\text { students at the school. Data were collected by using observation, interview, and } \\
\text { documentation techniques. The trustworthiness of data was tested by doing } \\
\text { triangulation. Then, the data were analyzed by using interactive model which } \\
\text { consisted of data reduction, display and verification/concluding. The result of this } \\
\text { study indicated that to optimize online learning during covid } 19 \text { pandemic, PAI } \\
\text { teachers used various platforms such as Whatsapp, google form, and google } \\
\text { meet. The teaching and learning process was done interactively and evaluated by } \\
\text { having mid-term test, final test, and portofolio. Furthermore, the teachers also } \\
\text { coordinated with parents about students difficulties in online learning, and } \\
\text { whenever necessary, the teachers did home visit. }\end{array}$ \\
\hline
\end{tabular}

Keywords: Islamic education teachers, online learning, covid 19

\begin{abstract}
Abstrak
Pandemi Covid 19 telah merubah sendi kehidupan masyarakat Indonesia terutama dalam dunia pendidikan. Penelitian ini bertujuan untuk mengetahui upaya guru Pendidikan Agama Islam (PAI) dalam mengoptimalkan pembelajaran daring di masa pandemi Covid-19. Penelitian ini menggunakan metode kualitatif dengan pendekatan deskriptif. Subjek penelitian guru mata pelajaran PAI di SMP Negeri 7 Sukoharjo, sementara informan penelitian ini yaitu Guru, Kepala sekolah dan siswa di SMP Negeri 7 Sukoharjo. Teknik pengumpulan data melalui observasi, wawancara, dan dokumentasi. Teknik keabsahan data menggunakan triangulasi data. Teknik analisis data yang menggunakan model interaktif dengan reduksi data, penyajian data, dan penarikan kesimpulan. Hasil penelitian ini menunjukkan bahwa upaya guru PAI dalam mengoptimalkan pembelajaran daring di massa pandemi Covid 19 dilakukan dengan menggunakan berbagai platform aplikasi seperti Whatsapp, google form, google meet. Metode pengajaran dilakukan dengan cara interaktif, sementara pelaksanaan evaluasi dilakukan dengan test tengah semester dan tes akhir semester, serta pengumpulan tugas individu berbentuk keahlian. Selanjutnya mengadakan koordinasi dengan orang tua mengenai kesulitan pembelajaran daring yang di alami anaknya, bila memerlukan, guru melaksanakan kunjungan ke rumah.
\end{abstract}

Kata Kunci: Guru Pendidikan Agama Islam, Pembelajaran Daring, Covid 19. 


\section{PENDAHULUAN}

Sejak pertama ditemukan di Kota Wuhan, suatu wabah yang bernama Covid-19 maka Organisasi Kesehatan Dunia (WHO) menetapkan dunia mengalami pandemi global, tak terkecuali hingga akhirnya sampai ke Indonesia. Virus ini mudah menular yang menyerang sistem pernapasan manusia dan mempengaruhi kondisi imunitas (Setiawan, 2020).

Hadirnya wabah tersebut memunculkan wacana digitalisasi di dalam dunia pendidikan dengan tujuan agar demi kegiatan belajar mengajar tetap berjalan dengan baik (Gumelar \& Dinnur, 2020; Jayul \& Irwanto, 2020). Dalam menyikapi adanya pandemi pemerintah Republik Indonesia telah memulai melakukan beberapa langkah strategis, guna menekan laju penyebaran virus COVID-19 yang kian masif di antaranya menerbitkan "Kepres Nomor 7 tahun 2020 dengan membentuk Gugus tugas percepatan Penanganan Virus COVID- 19". Serta juga telah menerbitkan Surat Edaran (SE) pada 18 Maret 2020 segala kegiatan di dalam dan di luar ruangan di semua sektor sementara waktu ditunda demi mengurangi penyebaran COVID-19 terutama pada bidang pendidikan (Dewi, 2020).

Kementerian Pendidikan pun juga menerbitkan "Surat Edaran (SE) Menteri Nomor 4 Tahun 2020 Pada tanggal 24 Maret 2020" yang berbunyi: meniadakan ujian nasional dan uji kompetensi keahlian pada sekolah kejuruan tahun 2020, proses belajar mengajar dilakukan dengan melaksanakan pembelajaran jarak jauh dari rumah secara daring. Ujian sekolah dan ujian kenaikan kelas pun dilakukan tanpa mengumpulkan peserta didik, tetapi hanya dilakukan hanya dengan cara mengukur melalui portofolio dan capaian peserta didik diperoleh saat belajar di rumah ataupun saat-sata sebelumnya. Sejalan dengan itu, sekolah pun tidak ambil diam dalam rangka pemutusan penyebaran virus ini juga menyediakan alat kebersihan, handsanitizer, dan masker bagi warga sekolah serta memberikan pembiayaan pembelajaran jarak jauh, agar pembelajaran tetap berjalan dengan baik (Farid, 2020).

Pembelajaran jarak jauh secara daring ini, tentulah terdapat beberapa hal yang harus dievaluasi, misalnya tentang kesulitan dalam penerapan pembelajaran daring. Berbagai penelitian telah mengkaji banyak temuan dalam pembelajaran daring dimasa Covid 19 yang menyebutkan bahwa faktanya tidak semua pelajar, terbiasa belajar melalui daring, apalagi guru juga masih banyak yang belum terampil mengajar dengan memanfaatkan teknologi internet atau media sosial utamanya pada daerah-daerah (Handayani, 2020; Purwanto et al., 2020; Putria et al., 2020). Penelitian lain yang dilakukan oleh (Warmansyah, 2020), menyebutkan bahwa perlu adanya program intervensi kembali bersekolah untuk mengantisipasi dari kekosongan peran sekolah dalam mendidik anak secara langsung akibat dari adanya pandemi yang mengharuskan siswa belajar dari rumah.

Menurut Roni Hamdani \& Priatna, (2020), dari temuan penelitiannya menyebutkan bahwa kesulitan untuk beradaptasi terutama guru-guru yang berusia lanjut, mereka yang sudah terbiasa mengajar secara konvensional sekaligus mereka 
tidak akrab dengan media daring, maka dipastikan mereka mengalami kesulitan dalam mengakses dan menggunakan aplikasi pembelajaran secara daring, sehingga dalam hal ini perlu penyesuaian dan pembiasaan, supaya pelaksanaan pembelajaran dapat berjalan lancar dan mencapai tujuan.

Temuan lain juga disampaikan oleh (2020), hambatan bagi peserta didik, bahwa murid-murid tidak bisa mencerna materi dengan baik, sebab pembelajaran daring dirasa hanya sebatas guru menerangkan melalui cuplikan tulisan melalui aplikasi, selebihnya peserta didik mengerjakan tugas yang diberikan secara mandiri. Padahal mereka belum sepenuhnya mengerti tentang materi yang diajarkan sebelumnya, ditambah lagi kebosanan juga kerap melanda. Oleh sebab itu, hambatan ini harus segera diatasi dan dievaluasi sehingga pembelajaran daring berjalan dengan efektif.

SMP Negeri 7 Sukoharjo yang berada di Desa Bulakrejo, Kec. Sukoharjo, Kab. Sukoharjo. Sekolah ini berada di bawah naungan Dinas Pendidikan Kabupaten Sukoharjo. Berdasarkan wawancara dengan Bapak Irfan selaku guru PAI di SMP N 7 Sukoharjo, didapatkan informasi bahwa SMP Negeri 7 Sukoharjo mengalami serta sangat merasakan dampak dari terjadinya pandemi Covid-19, sehingga Guru harus aktif dan berfikir cerdas agar jalannya pembelajaran tetap dilakukan dengan maksimal, misalnya dengan daring ini. (wawancara, 1 September 2020).

Bapak Irfan menambahkan bahwa pembelajaran daring pada semester yang lalu, mengalami berbagai hambatan, seperti misalnya guru yang terbiasa mengajarkan pembelajaran di kelas harus menyesuaikan diri dengan perangkat elektronik yang ada, baik dengan teknologi digital seperti Laptop, komputer, atau pun Handphone, serta juga aplikasi pertemuan daring seperti google classroom, google meet, dan whatsapp grub. Maka tak heran, jika para guru butuh waktu untuk memahaminya terlebih dahulu. Hal ini pula nantinya akan berpengaruh pada metode dan strategi para guru, demi suksesnya pembelajaran (wawancara, 1 September 2020).

Dalam pembelajaran jarak jauh secara daring menggunakan aplikasi Zoom, Google meet, dan Whatsapp grub. Tentu hal ini perlu persiapan yang matang, termasuk guru Pendidikan Agama Islam, sangat perlu langkah atau strategi yang tepat agar dapat menciptakan suasana pembelajaran jarak jauh secara daring yang menarik. Ketika proses pembelajaran tepat maka akan diikuti oleh peserta didik dengan mudah dan tidak terkesan monoton dan memberatkan juga.

Berangkat dari fenomena yang terjadi, serta melihat bagaimana upaya strategi guru PAI untuk memilih serta mengkreasikan metode dan media pembelajaran yang tepat, maka sangat penting untuk dilakukan penelitian, demi terciptanya pembelajaran daring yang optimal, khususnya di SMP Negeri 7 Sukoharjo.

\section{METODE PENELITIAN}

Penelitian meruapakan penelitian dengan jenis kualitatif deskriptif yang menganalisis data secara induktif, serta menggambarkan suatu peristiwa tertentu dengan gambar, atau bukan gambar dan juga kata-kata. Teknik pengumpulan data dalam 
penelitian ini menggunakan teknik dokumentasi, wawancara tidak terstruktur dan observasi tidak terstruktur, dengan menggunakan teknik ini maka peneliti akan mendapatkan data.

Penelitian ini dilaksanakan di SMP N 7 Sukoharjo. Dilaksanakan dengan bertahap, dimulai dari pengumpulan data dan wawancara, pengolahan data hingga penyajiannya dan kesimpulan. Subjek Penelitian ini adalah guru mata pelajaran PAI di SMP N 7 Sukoharjo. Informannya adalah Kepala Sekolah, Waka Kurikulum, Waka Kesiswaan dan siswa SMP N 7 Sukoharjo.

Seperti teori di atas, untuk memperoleh data dalam penelitian ini, penulis menggunakan beberapa metode pengumpulan data antara lain: metode observasi, yaitu metode mengamati atau berpartisipasi secara langsung guna memperoleh data berdasarkan fakta di lapangan. Dalam hal ini metode observasi partisipan, yaitu suatu kegiatan observasi di mana observer terlibat secara langsung dalam lingkungan kehidupan orang-orang yang diamati, agar memperoleh data tentang kegiatan pembelajaran daring yang dilakukan di SMP N 7 Sukoharjo, serta dapat melihat strategi apa yang digunakan guru PAI dalam memaksimalkan pembelajaran secara daring dan suasana pembelajaran daring tersebut. Dalam observasi partisipan ini, peneliti menyiapkan buku dan kamera agar bisa mudah mengumpulkan hal-hal yang penting selama pengamatan.

Kedua wawancara, yaitu proses pertemuan dua orang atau lebih untuk bertukar informasi, ide maupun gagasan melalui kegiatan tanya jawab sehingga dapat mengetahui permasalahan yang ada, wawancara juga digunakan agar penulis mengetahui secara mendalam berkaitan dengan subjek dan informan penelitian. Ketiga metode dokumentasi. Metode ini digunakan untuk mengetahui kegiatan pembelajaran, sejarah sekolah, visi-misi susunan organisasi, dan data-data lain di SMP N 7 Sukoharjo.

Teknik pengumpulan data melalui observasi, wawancara, dan dokumentasi. Teknik keabsahan data menggunakan triangulasi data. Teknik analisis data yang menggunakan model interaktif dengan reduksi data, penyajian data, dan penarikan kesimpulan.

\section{HASIL DAN PEMBAHASAN}

Upaya yang dilakukan guru PAI dalam rangka memaksimalkan pembelajaran daring, terbagi menjadi dua bagian, pertama saat sedang pembelajaran, kedua di luar pembelajaran. Kegiatan saat sedang pembelajaran meliputi, pembukaan, kegiatan inti pembelajaran, dan kegiatan penutup atau evaluasi. Hal tersebut selaras dengan pandangan Suyono (2015), menyatakan bahwa kegiatan pembelajaran merupakan sebuah proses pembelajaran yang meliputi kegiatan pokok, seperti kegiatan pendahuluan, kegiatan inti dan kegiatan penutup atau evaluasi.

Sedangkan kegiatan di luar pembelajaran meliputi, test evaluasi tengah semester maupun akhir semester, tugas portofolio, koordinasi dengan orang tua, serta kegiatan 
kunjungan kerumah siswa jika diperlukan. Kegiatan di luar pembelajaran ini tidak lain berfungsi sebagai penunjang kegiatan pembelajaran.

Sementara itu, bahwa kegiatan pembukaan atau persiapan, diawali dengan menyusun Rencana Pelaksanaan Pembelajaran (RPP). Tetapi, yang menarik adalah bahwa RPP pada tahun ajaran 2020-2021 ini berbeda dari RPP tahun-tahun sebelumnya. RPP yang disusun kini hanya berisi judul, mata pelajaran, tujuan pembelajaran, kegiatan pembelajaran, penilaian serta pengesahan tanda tangan dari kepala sekolah dan guru PAI, yang termuat dalam satu lembar kertas saja, dan karena RPP ini hanya digunakan untuk pembelajaran daring atau pembelajaran jarak jauh maka RPP ini dinamai sebagai RPP pembelajaran jarak jauh (RPP. PJJ)

Tetapi, bahwa sebenarnya RPP satu lembar ini, merupakan sebuah pengembangan penyusunan baru dari Kementerian Pendidikan, melalui "surat edaran nomor 14 tahun 2019, tentang penyederhanaan Rencana Pelaksanaan Pembelajaran (RPP)". Bahwa, di dalamnya menyatakan, "penyusunan Rencana Pelaksanaan Pembelajaran atau RPP dilakukan dengan prinsip, efisien, efektif, dan berorientasi pada siswa". Oleh sebab itu, SMP N 7 Sukoharjo yang notabene merupakan sekolah di bawah naungan kementerian pendidikan, maka kini menerapkan penyederhanaan RPP ini. Temuan ini sejalan dengan yang diteliti oleh Ritonga et al., (2020), yang menyebutkan bahwa organisasi profesi AGPAII meningkat setelah diadakannya pelatihan pembuatan soal dengan menggunakan google form. Kemampuan guru dalam membuat RPP dimasa daring dapat diaktualisasikan melalui pelatihan dan workshop RPP dengan memanfaatkan google form sebagai platformnya.

Setelah RPP tersusun, maka selanjutnya dalam pelaksanaan persiapan pembelajaran, seorang guru membuka tiga aplikasi, antara lain Whatsapp, Googgle form dan google classroom. Aplikasi ini tidak lain berfungsi sebagai media pembelajaran di masa Pandemi Covid-19 seperti sekarang ini, agar proses belajar mengajar tetap berjalan dengan lancar. Hal tersebut, senada dengan pendapat Rohmad (2016) bahwa media pembelajaran diarahkan dan digunakan untuk mempermudah proses belajar mengajar, sekaligus mempermudah untuk memahami materi pembelajaran, serta sebagai penghantar pesan pembelajaran. Seluruh aplikasi tersebut digunakan oleh guru PAI sebab masing-masing memiliki fungsi. Misalnya, Whatsapp difungsikan untuk melakukan interaksi oleh guru dengan siswa, mengirimkan materi serta untuk memancing minat siswa atau pun hanya digunakan untuk menginformasikan pengumuman. Sedangkan Google Classroom digunakan untuk mengumpulkan tugas, membagikan materi. Terakhir Google Form digunakan guru PAI untuk absensi dan ujian tengah semester maupun akhir semester.

Hal tersebut sejalan dengan penelitian yang dilakukan oleh Lubis et al., (2020), menyebutkan bahwa, banyak ragam upaya yang dapat dilakukan oleh guru PAI dalam menunjang pembelajaran agama Islam di masa belajar di rumah yaitu dengan memanfaatkan platform online yang sudah familia digunakan oleh guru dan siswa sebelum pandemi atau dimasa normal seperti, Whatsapp, mengirimkan video materi 
pembelajaran Pendidikan Islam, dan sesekali mempelajari Pendidikan Islam secara online dengan video call dan google meet. Penelitian lain juga menyebutkan bahwa "Penggunaan media online pada masa pandemi Covid-19 telah menimbulkan berbagai reaksi dan perubahan pada sistem pembelajaran yang dapat mempengaruhi proses belajar mengajar dan tingkat respon siswa terhadap materi yang disampaikan." (Jaelani et al., 2020). Penelitian yang dilakukan oleh Pratami \& Siregar, (2020), menemukan pembelajaran online pada mata pelajajaran PAI dapat meningkatkan nilai KKM siswa dengan memanfaatkan aplikasi seperti Zoom, Google Class Room dan Whatsaap.

Dalam melaksanakan pembelajaran metode yang di gunakan dalam pembelajaran daring adalah metode ceramah interaktif, metode ini dipilih karena tidak membosankan dan memiliki pola komunikasi dua arah antar guru dan siswa, ceramah interaktif melalui daring lebih menekankan kepada interaksi-interaksi pendek dan instruksi singkat dan dilanjutkan penyampaian pendapat dari siswa setelah itu diambil garis besarnya oleh guru. Proses Pembelajaran dimulai guru dengan mengingatkan kepada peserta didik untuk bersiap-siap menggunakan aplikasi Whatsappp, selanjutnya ketika proses pembelajaran dimulai, guru PAI mengawali dengan salam dan membaca surat al-fatihah secara mandiri, dilanjutkan dengan membaca surat pendek. Dalam kegiatan ini, seorang guru memulai dengan masuk kepada materi, misalnya guru mengajak siswa untuk berinteraksi dengan materi Asmaul Husna, di samping itu guru juga menggunakan aplikasi Google Classroom untuk mengunggah link video Asmaul Husna lalu siswa diminta untuk membukanya dan menghafalkannya. Begitu pun materimateri lainnya, yang jelas disesuaikan dengan sebuah materi.

Kegiatan penutup guru mengajak siswa untuk menyimpulkan pembelajaran, guru juga mengulas kembali proses pembelajaran serta menambahkan apa yang telah disimpulkan oleh para siswa. Sebelum pembelajaran ditutup, guru selalu berpesan untuk menjaga kesehatan dengan melakukan protokol kesehatan yang sudah ditentukan. Setelah itu baru guru menutup dengan membaca hamdalah bersama-sama dengan siswa serta mengucap salam.

Selanjutnya adalah kegiatan di luar pembelajaran, yaitu dilakukan evaluasi terstruktur dari pihak sekolah melalui ujian tengah semester maupun ujian akhir semester. Dalam rangka menilai dan melihat kualitas pemahaman siswa selama pembelajaran berlangsung, yang dilaksanakan tetap secara daring melalui google form sesuai waktu yang telah ditentukan oleh sekolah. Selain itu, ada kegiatan penunjang di luar pembelajaran, yaitu mengumpulkan portofolio yang berupa hafalan surat pendek maupun Asmaul Husna yang tela diajarkan di dalam proses pembelajaran. Pengumpulan portofolio dilakukan secara langsung siswa datang ke sekolah sesuai jadwal yang ditentukan, tidak lain juga hal ini untuk menilai kualitas siswa dari segi hafalannya.

Di samping itu juga, diadakan koordinasi kepada wali murid, sebab hal itu penting dilakukan agar keberhasilan sebuah pembelajaran daring. Tidak dipungkiri juga bahwa keberhasilan sebuah pembelajaran tidak akan dicapai tanpa campur tangan orang tua siswa. Sebab lain, bahwa di dalam pengawasan kepada putra-putrinya orang tualah 
yang sangat dominan. Tukar informasi menjadi penting, demi mengetahui kesulitan apa saja yang dialami dalam proses pembelajaran, dari informasi itu kemudian guru dan pihak sekolah juga bisa mengevaluasi proses pembelajaran, agar ke depan lebih baik dan mencapai tujuan.

Terakhir yaitu kunjungan siswa, hal ini dilakukan ketika misalnya ada seorang anak absen tiga kali, maka seorang guru mengunjungi atau menghubungi orang tua, dalam rangka menyelidiki agar mengetahui apa sebabnya tidak menguti pembelajaran, atau ketika misalnya siswa itu tidak mengerjakan tugas. Sebab, pembelajaran daring itu memang ada hal-hal yang menjurus kepada menyepelekan seorang guru. Setelah semua ini dijalankan, artinya kedua bagian dalam proses pembelajaran daring di SMP 7 Sukoharjo ini, berjalan dengan baik, sekaligus artinya menunjukkan jalannya proses pembelajaran dengan baik.

Dengan demikian guru mata pelajaran PAI harus terus berinovasi melakukan upaya peningkatan kompetensi pedagogi dan profesionalnya untuk menunjang pembelajaran dimasa pandemi covid 19, sebagaimana penelitian yang dihasilkan oleh (Novianti et al., 2020) menyebutkan bahwa "pelaksanaan pembelajaran jarak jauh guru PAI harus waspada dan berinovasi agar pelaksanaan pembelajaran terlaksana dengan baik".

\section{KESIMPULAN}

Upaya guru PAI dalam mengoptimalkan pembelajaran daring di SMP N 7 Sukoharjo, diawali dengan membuat Rencana Pelaksanaan Pembelajaran (RPP) yang sesuai dengan aturan terbaru dari pemerintah, yaitu RPP untuk pembelajaran jarak jauh. Guru PAI dalam proses pembelajaran menggunakan metode ceramah interaktif, tanya jawab melalui aplikasi pertemuan virtual seperti whatsapp, google meet dan google classroom. Sementara di luar pembelajaran seorang guru PAI melakukan evaluasi tengah semester maupun evaluasi akhir semester, melalui pengumpulan portofolio, serta guru melakukan koordinasi dengan wali murid dan juga melakukan kunjungan ke rumah siswa, agar melihat kondisi atau keadaan secara langsung.

\section{DAFTAR PUSTAKA}

Dewi, W. A. F. (2020). Dampak COVID-19 terhadap Implementasi Pembelajaran Daring di Sekolah Dasar. EDUKATIF : JURNAL ILMU PENDIDIKAN, 2(1), 5561. https://doi.org/10.31004/edukatif.v2i1.89

Farid, M. (2020). Kebijakan Politik Presiden Jokowi Terhadap Masalah Kewarganeraan dalam Merespons Isu Global: Studi Kasus Covid-19. Citizenship Jurnal Pancasila dan Kewarganegaraan, 8(1), 1-12. Citizenship Jurnal Pancasila Dan Kewarganegaraan, $\quad 8(1), \quad 1-12$. https://doi.org/http://doi.org/10.25273/citizenship.v8i1.6216

Gumelar, D. R., \& Dinnur, S. S. (2020). Digitalisasi Pendidikan Hukum Dan Prospeknya Pasca Pandemi Covid-19. Al-Ahwal Al-Syakhsiyyah: Jurnal Hukum 
Keluarga Dan Peradilan Islam, 1(2), 111-122. https://doi.org/10.15575/as.v1i2.9909

Handayani, L. (2020). Keuntungan , Kendala dan Solusi Pembelajaran Online Selama Pandemi Covid-19: Studi Ekploratif di SMPN 3 Bae Kudus Lina Handayani. Journal Industrial Engineering \& Management Research, 1(2), 16.

Jaelani, A., Fauzi, H., Aisah, H., \& Zaqiyah, Q. Y. (2020). Penggunaan Media Online Dalam Proses Kegiatan Belajar Mengajar Pai Dimasa Pandemi Covid-19 (Studi Pustaka dan Observasi Online). Jurnal IKA PGSD (Ikatan Alumni PGSD) UNARS, 8(1), 12. https://doi.org/10.36841/pgsdunars.v8i1.579

Jayul, A., \& Irwanto, E. (2020). Model Pembelajaran Daring Sebagai Alternatif Proses Kegiatan Belajar Pendidikan Jasmani di Tengah Pandemi Covid-19 Achmad. Jurnal Pendidikan Kesehatan Rekreasi, 6(2), 191.

Lubis, M., Nasution, M., Gemilasari, C., \& Fakhruddin, F. (2020). Ragam Alternatif Strategi Pembelajaran Pai Selama Masa Pandemi Covid-19 Di SDIT Al-Munadi Medan. Jurnal Bilqolam Pendidikan Islam, 1(2), 98-114. https://doi.org/10.51672/jbpi.v1i2.3

Novianti, E., Fatkhia, A. R., \& Nuryana, Z. (2020). Analisis Kebijakan Pembelajaran PAI di Masa Pandemi: Peluang Dan Tantangan. Jurnal Pendidikan Islam, 11(2). https://doi.org/https://doi.org/10.22236/jpi.v11i2.5663

Oktawirawan, D. H. (2020). Faktor Pemicu Kecemasan Siswa dalam Melakukan Pembelajaran Daring di Masa Pandemi Covid-19. Jurnal Ilmiah Universitas Batanghari Jambi, 20(2), 541. https://doi.org/10.33087/jiubj.v20i2.932

Pratami, F., \& Siregar, S. D. (2020). Optimalisasi Peran Guru Pai Terhadap Hasil Belajar Siswa Masa Pandemi Covid-19. Edu Global: Jurnal Pendidikan ..., 1(1), $25-35$.

Purwanto, A., Pramono, R., Asbari, M., Santoso, P. B., Wijayanti, L. M., Choi, C. H., \& Putri, R. S. (2020). Studi Eksploratif Dampak Pandemi COVID-19 Terhadap Proses Pembelajaran Online di Sekolah Dasar. EduPsyCouns: Journal of Education, Psychology and Counseling, 2(1), 1-12. https://ummaspul.ejournal.id/Edupsycouns/article/view/397

Putria, H., Maula, L. H., \& Uswatun, D. A. (2020). Analisis Proses Pembelajaran dalam Jaringan (DARING) Masa Pandemi Covid- 19 Pada Guru Sekolah Dasar. Jurnal Basicedu, 4(4), 861-870. https://doi.org/10.31004/basicedu.v4i4.460

Ritonga, M., Lahmi, A., Rimelfi, R., Bahri, F., \& Bagindo, I. T. (2020). Sosialisasi Pembuatan Soal Melalui Google Form Dalam Meningkatkan Kompetensi Guru PAI. BERNAS: Jurnal Pengabdian Kepada Masyarakat, 1(4), 347-354. https://doi.org/10.31949/jb.v1i4.456

Rohmad. (2016). Memahami Teori Teknologi Pembelajaran dalam Pendidikan Islam . Gerbang media. 
Roni Hamdani, A., \& Priatna, A. (2020). Efektifitas Implementasi Pembelajaran Daring (Full Online) Dimasa Pandemi Covid- 19 Pada Jenjang Sekolah Dasar Di Kabupaten Subang. Didaktik: Jurnal Ilmiah PGSD STKIP Subang, 6(1), 1-9. https://doi.org/10.36989/didaktik.v6i1.120

Setiawan, A. R. (2020). Students' Worksheet for Distance Learning Based on Scientific Literacy in the Topic Coronavirus Disease 2019 (COVID-19) Adib. Edukatif, 21(1), 1-9.

Suyono. (2015). Belajar dan Pembelajaran teori dan konsep dasar (Cet 5). Rosdakarya.

Warmansyah, J. (2020). Program Intervensi Kembali Bersekolah Anak Usia Dini Masa Pandemi Covid-19. Jurnal Obsesi : Jurnal Pendidikan Anak Usia Dini, 5(1), 743. https://doi.org/10.31004/obsesi.v5i1.573 